\title{
DATING AND STABLE ISOTOPE ANALYSIS OF CHARRED RESIDUES ON THE INCIPIENT JOMON POTTERY (JAPAN)
}

\author{
Kunio Yoshida ${ }^{1,2} \cdot$ Dai Kunikita $^{3}$ - Yumiko Miyazaki ${ }^{1}$ - Yasutami Nishida ${ }^{4}$ Toru Miyao M $^{4}$ \\ Hiroyuki Matsuzaki ${ }^{5}$
}

\begin{abstract}
This study reports radiocarbon dates of more than 30 samples of charred residues on pottery sherds of the Incipient Jomon period. The ages of Linear-relief (Ryukisenmon) pottery were 15,300-13,700 cal BP, with great differences among the samples. The pitted decoration (Enkomon), Nail-impressed (Tsumegatamon), and pressing and dragging (Oshibikimon) types date to 13,800-12,400 cal BP. For pottery of the same type, differences among sites were large. At the Unokiminami site, the impressed cord mark (Oatsu Jomon) is the main pottery type, including Nail-impressed. The latter shows a slightly older age. Stable isotope and elemental analyses were used to ascertain the origin of charred residues on the pottery. In the data set of Jomon pottery of the oldest type, residues consisting only of cooked nuts were found. However, Jomon people, even from early times, are thought to have cooked mixed plant and animal ingredients, including marine products.
\end{abstract}

\section{INTRODUCTION}

Pottery-making started in the terminal Late Pleistocene in Japan (Nakamura et al. 2001), China (Boaretto et al. 2009), and the Russian Far East (Kuzmin 2006). Recently, the emergence of pottery in China was dated possibly back to 20,000 yr ago based on samples from Xianrendong Cave, Jiangxi, China (Wu et al. 2012).

The Incipient Jomon period in Japan can be divided into 4 phases according to changes in the pottery type (Taniguchi 2011): Phase 1 (before Linear-relief) of 16,540-15,250 cal BP; Phase 2 (Linearrelief or decorated with slender clay ridges [Ryukisenmon]): 15,190-13,500 cal BP; Phase 3a (pitted decoration [Enkomon], Nail-impressed or decorated with crescent-impressed patterns [Tsumegatamon], and impressed cord mark [Oatsu Jomon]): 14,840-12,090 cal BP; and Phase 3b (rolled cord impression [Kaitenjomon] and others): 11,970-11,240 cal BP.

The analyzed samples are thought to belong to 2nd and 3rd groups above based on pottery type. Phase 2 corresponds to the Bølling oscillation, the first interstadial GI-1e after the Last Glacial Maximum (Lowe et al. 2008). The varve chronology of Lake Suigetsu indicates changes in the sedimentation rate and sedimentary processes in the period around $12.6 \mathrm{kyr}$ BP (Bronk Ramsey et al. 2012). It is interesting that dates of the Linear-relief type are in the same range. Phase 3a corresponds to the Allerød oscillation, while Phase $3 \mathrm{~b}$ is in the range of the Younger Dryas stadial.

Clarifying the purposes of use of earthenware vessels in the early days of pottery-making presents an important problem. Determining the kinds of food components eaten by ancient people, methods of getting food, and the manner of cooking are crucially important subjects in the fields of archaeology and anthropology. Stable isotopic analysis is an extremely powerful tool in the elucidation of paleodiet. The approach uses charred materials on the pottery surface. The materials are presumed to be residues of cooked food and the remaining information exists to reveal raw materials cooked by ancient populations for meals (Yoshida 2006). They are the results of one or a few cooking expe-

\footnotetext{
${ }^{1}$ The University Museum, The University of Tokyo, 7-3-1 Hongo, Bunkyo-ku, Tokyo 113-0033, Japan.

${ }^{2}$ Corresponding author. Email: gara@um.u-tokyo.ac.jp.

${ }^{3}$ Graduate School of Humanities and Sociology, Tokoro Research Lab., The University of Tokyo, 384 Sakaeura, Tokoro-cho, Kitami-shi, Hokkaido 093-0216, Japan.

${ }^{4}$ Niigata Prefectual Museum of History, Sekihara 1, Nagaoka, Niigata 940-2035, Japan.

${ }^{5}$ School of Engineering, The University of Tokyo, 2-11-16 Yayoi, Bunkyo-ku, Tokyo 113-0032, Japan.
}

C 2013 by the Arizona Board of Regents on behalf of the University of Arizona

Proceedings of the 21st International Radiocarbon Conference edited by A J T Jull \& C Hatté

RADIOCARBON, Vol 55, Nr 2-3, 2013, p 1322-1333 


\section{$K$ Yoshida et al.}

riences. To shed light on the diet of ancient people of the Jomon culture, they are a powerful resource.

Recently, some researchers have reported freshwater and marine reservoir effects observed for bone collagen and charred residue from inland archaeological sites. Yoneda et al. (2004a) reported isotopic evidence of bones for inland-water fishing by a Jomon population of Nagano Prefecture. Fisher and Heinemeier (2003) expected a freshwater effect on the radiocarbon dates of charred materials in Denmark, but Hart and Lovis (2007) compiled dates of the site and claimed only a single outlying date. Boudin et al. (2010) analyzed stable isotope values for fresh and charred/heated modern material to study thermal degradation. Kunikita et al. (2007) reported the marine reservoir effect on charred materials at an inland site of Primorye [Maritime] Province in the Russian Far East. This study and those above highlight the importance of measuring ${ }^{14} \mathrm{C}$ dates and $\mathrm{C}: \mathrm{N}$ ratios simultaneously.

\section{MATERIALS AND METHOD}

About 50 sites of the Incipient Jomon period are located around Tsunan-machi $\left(37.0^{\circ} \mathrm{N}, 138.7^{\circ} \mathrm{E}\right)$ in Niigata Prefecture, where the Shinano River and Kiyotsu River flow together. Pottery sherds of 6 ruins in that area and 2 ruins from another region were analyzed. The analyzed samples were charred residues on the surface of pottery from the Incipient Jomon period excavated from the following 8 archaeological sites located in Niigata Prefecture: 5 ruins are in Tokamachi City, as the Kuboderaminami site (4 vessels), the Komaruyama B site (1), the Jin site (5), the Nakada D site (3), and the Ozakashimizu site (2). Other sites include Saigura site (Nagaoka City, 4), Kosegasawadokutsu (Aga Town, 1), and Unokiminami site (Tsunan Town, 23).

After the excavation was conducted by archaeologists, we selected the vessels and potsherds with adherent charred materials. Samples of 1-230 mg in weight were scraped off using metal tools and collected on aluminum foil. Forty-three samples for 34 individuals were mainly collected from the outer wall of the pottery rim. To remove the contaminants for ${ }^{14} \mathrm{C}$ dating, samples were subjected to in acid-alkali-acid (AAA) pretreatment at room temperature or at $80^{\circ} \mathrm{C}$ (Yoshida et al. 2004). Alkaline treatment was done at concentrations of 0.0025 to $1.2 \mathrm{M} \mathrm{NaOH}$ according to the condition of the sample, and stopped at $0.01 \mathrm{M}$ in many cases. For charred residues, samples are treated using acetone in an ultrasonic bath for eliminating binder and/or materials for ink rubbing before AAA pretreatment. The process of oxidation and reduction to the graphite sample was the same as that described in Yoshida and Miyazaki (2001). ${ }^{14} \mathrm{C}$ dates were determined at the MALT facility, University of Tokyo (Kunikita et al. 2007) and were calibrated using IntCal09 data (Reimer et al. 2009) with the calibration program OxCal v 4.1.6 (Bronk Ramsey 2009).

The remainder of the sample was used to analyze the atomic and isotopic ratios for $\mathrm{C}$ and $\mathrm{N}$. Typically, $0.05-0.1 \mathrm{mg}$ of sample were measured for the C:N and $\delta^{13} \mathrm{C}$ ratios and $1-3 \mathrm{mg}$ for the $\delta^{15} \mathrm{~N}$ ratio. Measurements were performed using an elemental analyzer connected to an isotope ratio mass spectrometer (EA3028-HT and IsoPrime, IsoPrime EA; Micromass, UK). The uncertainties in the system are estimated as $0.1 \%$ for $\delta^{13} \mathrm{C}$ and $0.3 \%$ for $\delta^{15} \mathrm{~N}$.

\section{RESULTS AND DISCUSSION}

\section{Radiocarbon Age}

The ${ }^{14} \mathrm{C}$ ages for charred residues on Jomon potteries are listed in Tables 1 and 2, and the ranges of calibrated ages are given in Figure $1 .{ }^{14} \mathrm{C}$ dates are distributed span 10,500 to 12,700 BP, and are divisible into an old group of about 12,500 BP and a group younger than 12,000 BP. 


\section{Charred Residues on Incipient Jomon Pottery}

Table $1{ }^{14} \mathrm{C}$ dates for the charred residue on pottery from the site in the Tsunan-machi region and others.

\begin{tabular}{|c|c|c|c|c|c|c|c|}
\hline Site & Sample $n r^{\mathrm{a}}$ & Type & $\begin{array}{l}{ }^{14} \mathrm{C} \text { age } \\
\mathrm{BP}(1 \sigma)\end{array}$ & $\begin{array}{l}\delta^{13} \mathrm{C} \\
(\%)\end{array}$ & $\begin{array}{l}\delta^{15} \mathrm{~N} \\
(\%)\end{array}$ & $\mathrm{C} / \mathrm{N}$ & $\begin{array}{l}\text { Lab nr } \\
\text { (TKa-) }\end{array}$ \\
\hline \multirow[t]{4}{*}{ Kuboderaminami } & KBM-F2-792 & Linear-relief & $12,690 \pm 110$ & & & & 14586 \\
\hline & KBM-1T-208 & Linear-relief & $12,670 \pm 170$ & -26.8 & - & 43.9 & 14587 \\
\hline & KBM-F2-792 & Linear-relief & $12,460 \pm 90$ & & & & 14598 \\
\hline & KBM-G2-308 & Linear-relief & $12,640 \pm 90$ & -26.9 & - & 52.1 & 15463 \\
\hline Komaruyama B & KY-K-7-23-1 & Linear-relief & $11,940 \pm 50$ & -25.6 & 2.1 & 12.3 & 14554 \\
\hline \multirow[t]{5}{*}{ Jin } & HY 32-1-1 1 & Pitted decoration & $11,800 \pm 60$ & -23.8 & 13.3 & 12.0 & 14552 \\
\hline & HY 32-1-1 2 & Pitted decoration & $11,670 \pm 80$ & & & & 15459 \\
\hline & HY 32-1-1 (3) & Pitted decoration & $11,690 \pm 90$ & & & & 15460 \\
\hline & $91 \mathrm{JE}-614$ & Pitted decoration & $11,700 \pm 90$ & -26.0 & - & 19.3 & 14594 \\
\hline & 91 JE-9-24 & Pitted decoration & & -25.1 & - & 35.4 & \\
\hline \multirow[t]{4}{*}{ Saigura } & HY 34 & Nail-impressed & $11,760 \pm 120$ & -23.8 & 12.0 & 9.3 & 14599 \\
\hline & HY 37- (2) -1 & Nail-impressed & $11,760 \pm 80$ & & & & 15462 \\
\hline & HY 37- (2) -2 & Nail-impressed & $11,570 \pm 80$ & -25.1 & 13.2 & 11.3 & 14584 \\
\hline & HY 37- 1 & Nail-impressed & $11,550 \pm 60$ & -24.5 & - & 10.6 & 14551 \\
\hline \multirow[t]{3}{*}{ Nakada D } & 109 & Plain & $11,610 \pm 50$ & -25.6 & 9.8 & 21.2 & 14556 \\
\hline & $24 \mathrm{~T}-24$ & Nail-impressed & $11,440 \pm 80$ & & & & 15461 \\
\hline & 2 & Nail-impressed & $11,340 \pm 120$ & -25.8 & - & 20.4 & 14588 \\
\hline \multirow[t]{2}{*}{ Ozakashimizu } & B4-16-3 & Pressing \& dragging & $10,740 \pm 110$ & & & & 14596 \\
\hline & B4-16-25 & Pressing \& dragging & $10,670 \pm 140$ & & & & 14597 \\
\hline Kosegasawa & HY 83 & Nail-impressed & $10,510 \pm 60$ & -27.0 & - & 38.9 & 14564 \\
\hline
\end{tabular}

${ }^{a}$ Circled numbers indicate different potsherds of the same pottery.

\section{Phase 2: Linear-relief (Ryukisenmon) Pottery}

The calibrated ${ }^{14} \mathrm{C}$ ages for the "Linear-relief type" of the Kuboderaminami site are distributed between 15,200 and 14,200 cal BP, consistent with the previously reported values (Tsuji 2001). The same type pottery at the Komaruyama B site is apparently about 1000 cal BP younger. It is similar to the age of pottery of the same type from the Seikosanso B site, Nagano Prefecture and the last stage of phase 2. The range of 15,200-13,600 cal BP is the same as that for the compiled data for Phase 2 (Taniguchi 2011).

Phase 3a: Pitted Decoration (Enkomon), Nail-Impressed or Decorated with Crescent-Impressed Patterns (Tsumegatamon), and Impressed Cord Mark (Oatsu Jomon) Pottery

The ages for the "pitted decoration" type at the Jin site fall between 13,800 and 13,400 cal BP. Ages for the "Nail-impressed" type are somewhat younger than the pitted decoration type, although some data show the same values as those for HY 34 and HY 37-2-1 in Figure 1. Tsumegatamon is crescent patterns and fingernail-like impressions made by the inner rim of split bamboo. The ages for the Saigura site pottery continued to $13,300 \mathrm{cal}$ BP, and those of the Nakada D site are 13,400-13,100 cal BP. The Kosegasawadokutsu site is by far the youngest, about 12,500 cal BP. Oshibikimon pots have linear patterns of impressions created by obliquely pressing and dragging into the surface. The age for the Oshibikimon pottery found at the Ozakashimizu site is 12,800-12,400 cal BP. 


\section{K Yoshida et al.}

Table $2{ }^{14} \mathrm{C}$ dates for the charred residue on pottery from the Unokiminami site. ${ }^{\text {a }}$

\begin{tabular}{|c|c|c|c|c|c|c|c|c|}
\hline Type & $\begin{array}{l}\text { Sample } \\
\mathrm{nr}\end{array}$ & Parts & & $\begin{array}{l}{ }^{14} \mathrm{C} \text { age } \\
\mathrm{BP}(1 \sigma)\end{array}$ & $\begin{array}{l}\delta^{13} \mathrm{C} \\
(\%)\end{array}$ & $\begin{array}{l}\delta^{15} \mathrm{~N} \\
(\%)\end{array}$ & $\mathrm{C} / \mathrm{N}$ & $\begin{array}{l}\text { Lab nr } \\
\text { (TKa-) }\end{array}$ \\
\hline $1 \mathrm{a}$ & $\begin{array}{l}14 \\
236 \\
241 \\
2013\end{array}$ & $\begin{array}{l}\text { Body } \\
\text { Body } \\
\text { Body } \\
\text { Rim }\end{array}$ & $\begin{array}{l}\text { Outer } \\
\text { Inner } \\
\text { Outer } \\
\text { Outer } \\
\text { Outer } \\
\text { Inner }\end{array}$ & $\begin{array}{l}11,070 \pm 100 \\
10,810 \pm 70 \\
10,920 \pm 70\end{array}$ & $\begin{array}{l}-25.3 \\
-27.1 \\
-25.0 \\
-23.9 \\
-25.2 \\
-26.0\end{array}$ & $\begin{array}{r}11.4 \\
6.9 \\
12.1 \\
16.2 \\
12.0 \\
8.4\end{array}$ & $\begin{array}{l}20.1 \\
17.9 \\
14.2 \\
10.7 \\
21.1 \\
10.0\end{array}$ & $\begin{array}{l}14620 \\
14611 \\
14622\end{array}$ \\
\hline $1 b$ & $\begin{array}{l}324 \\
325\end{array}$ & $\begin{array}{l}\text { Rim } \\
\text { Body }\end{array}$ & $\begin{array}{l}\text { Outer } \\
\text { Outer } \\
\text { Inner }\end{array}$ & $\begin{array}{l}10,920 \pm 70 \\
10,860 \pm 70\end{array}$ & $\begin{array}{l}-25.4 \\
-24.8 \\
-22.7\end{array}$ & $\begin{array}{l}12.1 \\
12.9 \\
13.2\end{array}$ & $\begin{array}{r}11.8 \\
12.4 \\
7.9\end{array}$ & $\begin{array}{l}14623 \\
14612\end{array}$ \\
\hline $1 \mathrm{c}$ & $\begin{array}{l}401 \\
2015\end{array}$ & $\begin{array}{l}\text { Body } \\
\text { Rim }\end{array}$ & $\begin{array}{l}\text { Outer } \\
\text { Outer }\end{array}$ & $\begin{array}{l}10,850 \pm 130 \\
10,850 \pm 70\end{array}$ & $\begin{array}{l}-24.0 \\
-25.1\end{array}$ & 14.3 & $\begin{array}{l}10.2 \\
21.9\end{array}$ & $\begin{array}{l}14591 \\
14613\end{array}$ \\
\hline $2 \mathrm{a}$ & $\begin{array}{l}611 \\
613 \\
614 \\
2010\end{array}$ & $\begin{array}{l}\text { Body } \\
\text { Rim } \\
\text { Body } \\
\text { Rim }\end{array}$ & $\begin{array}{l}\text { Outer } \\
\text { Outer } \\
\text { Inner } \\
\text { Outer } \\
\text { Outer }\end{array}$ & $\begin{array}{l}10,830 \pm 80 \\
10,900 \pm 70 \\
10,880 \pm 70 \\
10,790 \pm 70\end{array}$ & $\begin{array}{l}-25.0 \\
-24.2 \\
-23.6 \\
-24.6 \\
-24.6\end{array}$ & $\begin{array}{l}13.5 \\
13.2\end{array}$ & $\begin{array}{r}9.9 \\
11.1 \\
11.6 \\
14.2 \\
16.3\end{array}$ & $\begin{array}{l}14624 \\
14625 \\
14626 \\
14614\end{array}$ \\
\hline $2 b$ & 2011 & Rim & Outer & & -25.6 & 12.3 & 18.3 & \\
\hline $2 \mathrm{c}$ & 621 & Rim & Outer & & -24.9 & 13.3 & 14.6 & \\
\hline $3 b$ & 2021 & Rim & $\begin{array}{l}\text { Outer } \\
\text { Inner }\end{array}$ & $\begin{array}{l}10,990 \pm 80 \\
11,000 \pm 60\end{array}$ & $\begin{array}{l}-25.2 \\
-23.5\end{array}$ & 11.8 & $\begin{array}{r}12.2 \\
6.9\end{array}$ & $\begin{array}{l}14581 \\
14615\end{array}$ \\
\hline $5 b$ & 624 & Rim & Outer & $10,950 \pm 120$ & -25.3 & & 11.9 & 14582 \\
\hline 7 & $\begin{array}{l}3001 \\
3002\end{array}$ & $\begin{array}{l}\text { Body } \\
\text { Rim }\end{array}$ & $\begin{array}{l}\text { Outer } \\
\text { Outer }\end{array}$ & $\begin{array}{l}10,990 \pm 60 \\
11,670 \pm 130\end{array}$ & $\begin{array}{l}-25.6 \\
-21.9\end{array}$ & 18.1 & $\begin{array}{r}19.4 \\
6.7\end{array}$ & $\begin{array}{l}14616 \\
14583\end{array}$ \\
\hline
\end{tabular}

${ }^{a}$ Excavated potteries are classified as 7 types: Type 1: impressed cord mark is mainly (a: multistage patterns by thick cord, b: slanting multistage patterns, c: by the tip or the ring of cord); Type 2: impressed cord mark is mainly, and "Ha in Japanese katakana [slanted roof]" shape nail-like pattern is used in combination (a: correct position, b: inversion, c: oblique); Type 3: pattern made by impressing a side of thin, long cord; Type 4: pattern made by impressing a cord-wrapped stick; Type 5: Nail-impressed mainly; Type 6: pressing and drawing pattern; Type 7: plain.

Calibrated ages of pottery from the Unokiminami site are shown in Figure 1. Most ages lie in the period 13,000-12,600 cal BP, between the age of the Nakada D and Kosegasawadokutsu sites, and is similar to the age of the Ozakashimizu site. The ages of type 3, impressing a cord-wrapped stick, and type 5, Nail-impressed only, are rather old: about 100 yr. The paired samples, residues on the outside of the potsherd and those on the inner side, are dated and mutually compared. The paired data are marked with a square frame in Figure 1. The adhered region of the vessel shows different results. Samples 14 and 325 were taken from the body of the vessel, and other paired samples are from the rim. Sample 14 (outside) was probably affected by the "old wood effect."

\section{Native Food Components in the Japanese Archipelago}

Table 3 and Figure 2 show isotopic values of typical native components collected in the Japanese Archipelago (this work; Shimojo 1988; Minagawa 2001). The ellipse in Figure 2 marks the $\pm 2 \sigma$ range of each group. Isotopic values of flesh are estimated from those of animal bone collagen 


\section{Charred Residues on Incipient Jomon Pottery}

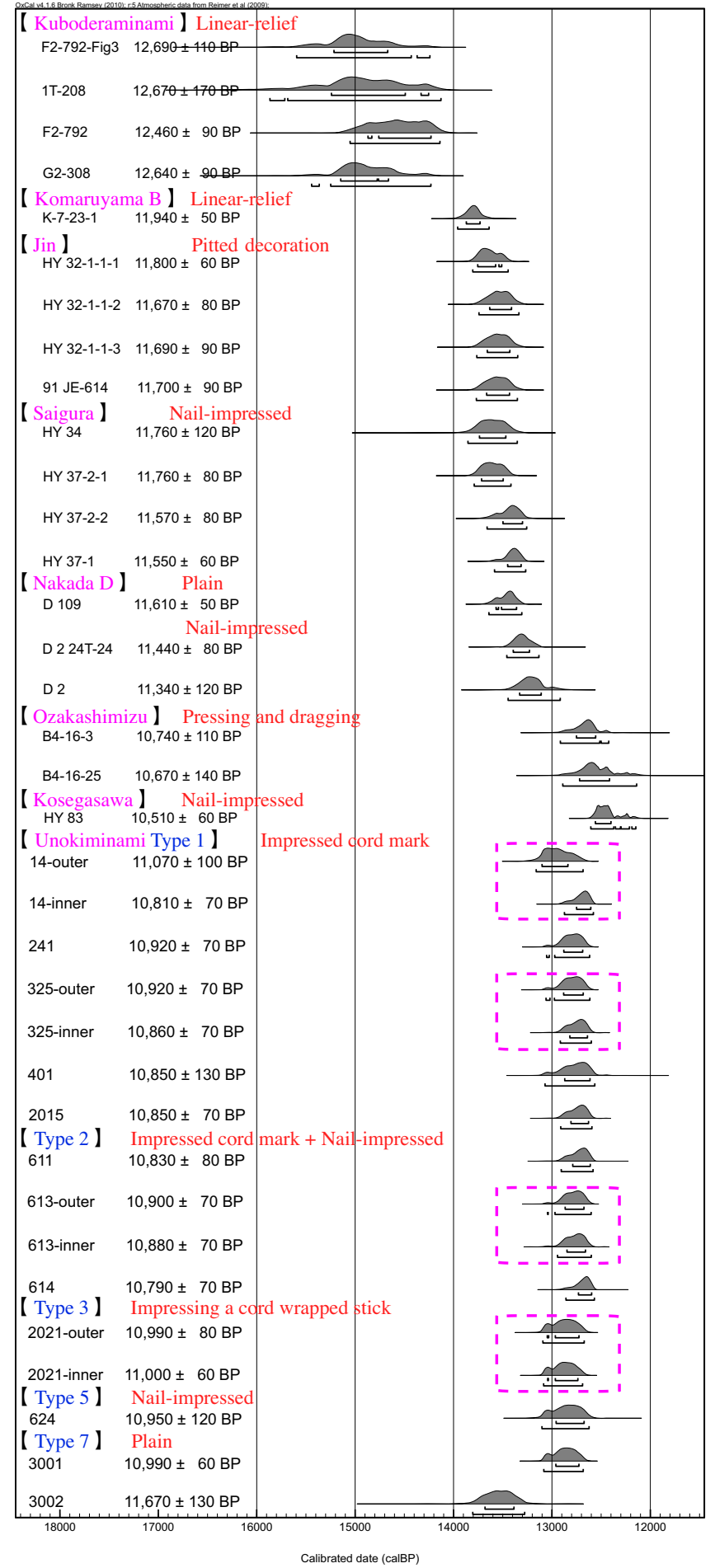

Figure 1 Calibrated age of the charred residues on pottery. Calibrated ages are calculated using the IntCal09 data set and OxCal v 4.1.6 software. 


\section{K Yoshida et al.}

including marine fish as $-2.4 \%$ for $\delta^{13} \mathrm{C}$ and $-0.8 \%$ for $\delta^{15} \mathrm{~N}$ (Yoneda et al. 2004b). Specimens of shellfish, salmon, and parts of plants are modern samples. The carbon isotopic values of those are shifted by $+1.6-1.8 \%$ for terrestrial samples and $+0.5 \%$ for marine samples, which could signal the Suess effect in the $\delta^{13} \mathrm{C}$ results (IPCC 2007). Other samples were excavated from the archaeological site. For plants, excavated samples are carbonized. The values corrected using the Suess effect for carbon isotopes on modern plants are consistent with archaeological samples.

Table 3 Carbon and nitrogen isotopic ratios of Japanese native food components.

\begin{tabular}{lrrl}
\hline Food group & \multicolumn{1}{c}{$\delta^{13} \mathrm{C}(\%)$} & \multicolumn{1}{c}{$\delta^{15} \mathrm{~N}(\%)$} & Number $^{\mathrm{a}}$ \\
\hline $\mathrm{C}_{3}$ plants & $-25.9 \pm 2.0$ & $1.4 \pm 2.8$ & $63(47)$ \\
$\mathrm{C}_{4}$ plants & $-9.8 \pm 0.9$ & $2.9 \pm 2.3$ & 12 \\
Terrestrial mammal & $-24.0 \pm 0.7$ & $3.7 \pm 1.4$ & $17(16)$ \\
Marine shellfish & $-14.8 \pm 1.6$ & $8.4 \pm 2.1$ & 14 \\
Marine finfish & $-14.1 \pm 1.3$ & $12.6 \pm 1.8$ & 18 \\
Salmon & $-16.9 \pm 0.8$ & $11.2 \pm 1.2$ & 7 \\
Marine mammal & $-16.3 \pm 1.3$ & $15.1 \pm 1.9$ & 11 \\
\hline
\end{tabular}

${ }^{a}$ In parentheses is the number of samples measured for carbon and nitrogen isotope ratios.

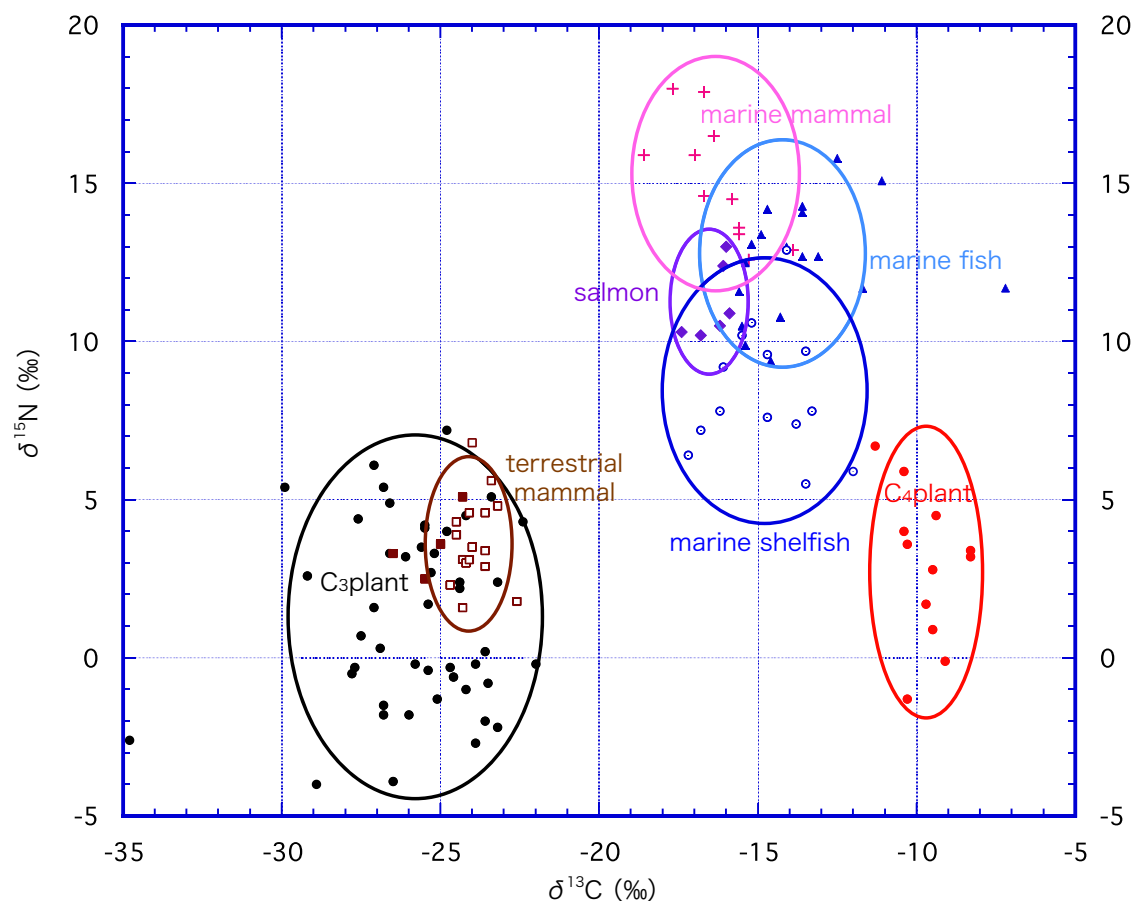

Figure 2 Carbon and nitrogen isotopic ratios of Japanese native food components (ellipses in the figure mark the $2 \sigma$ ranges of each group).

\section{Isotopic Ratios Before and After Carbonization}

To confirm whether information of isotopic ratios was lost during carbonization of food, we cooked various cooking ingredients using unglazed pottery of caliper shape (Nishida 2006). Modern food 
material and water were poured into a vessel of about $25 \mathrm{~cm}$ height. The vessel was placed on a calm open-air fire or the cinders, and the contents were cooked until the water disappeared.

Cooking experiments of 50 kinds of ingredients have been conducted for seeds and grains such as red beans and foxtail millet, nuts such as acorns and horse chestnuts and chestnuts, bulbs and yam, animals such as black bears (Ursus Thibetanus japonicas), Shika deer (Cervus nippon), and raccoon dogs, and fish such as salmon. Almost all were regarded as food materials. Stable isotopic analyses were done on the raw materials and charred residues.

Results show that information related to the stable isotopes of carbon and nitrogen $\left(\delta^{13} \mathrm{C}\right.$ and $\left.\delta^{15} \mathrm{~N}\right)$ were mostly maintained (Yoshida 2006). The change of isotopic ratios is small for carbon, within $\pm 2 \%$, excluding 1 sample (Figure 3 ). For the factor of change, as for the residual solid, the ratio of heavy isotopes increases if lipids are lost by heating because lipids contain many light isotopes compared to carbohydrates. Poole et al. (2002) reported the result of a heating experiment using peas and they showed a change of $\sim 2 \%$ in $\delta^{13} \mathrm{C}$, but the direction of the change was not the consistent. On the other hand, the $\delta^{15} \mathrm{~N}$ values increase in all samples except for the raccoon dog. In the red bean and sesame, the $\delta^{15} \mathrm{~N}$ ratio increases considerably (about $+4 \%$ ). It is necessary to examine the chemical change by processes such as the Maillard reaction when protein is carbonized. The carbon to nitrogen ratio $(\mathrm{C}: \mathrm{N})$ values were able to distinguish starchy matter as nuts from other ordinary $\mathrm{C}_{3}$ plants (Figure 4).

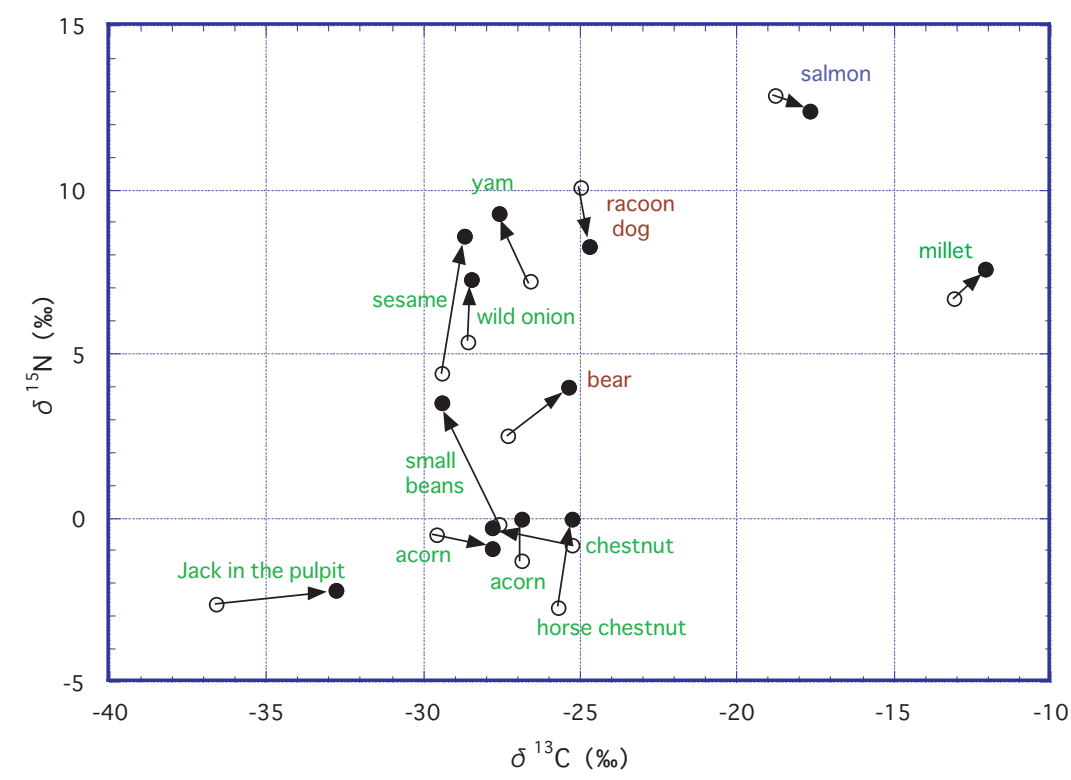

Figure 3 Change of carbon and nitrogen isotope ratios before and after cooking (open circles show values of raw materials and closed circles show values of carbonized materials).

The isotope ratios of the prehistoric carbonized plants are similar to those of their modern counterparts, but the $\delta^{15} \mathrm{~N}$ values of uncarbonized plants are 10-20\% more positive than those of modern ones, while carbonized plants remain similar (DeNiro and Hastorf 1985). Thermal treatments (at $200^{\circ} \mathrm{C}$ ) for wild boar, bream, hazelnut, turnip, and wheat were done in laboratory conditions and the $\delta^{13} \mathrm{C}$ varied from -0.3 to $+0.5 \%$ and those of $\delta^{15} \mathrm{~N}$ from -0.2 to $+1.5 \%$ between before and after treatment. As a result, the atomic ratios (C:N) changed greatly as well (Boudin et al. 2010). Overall, 


\section{$K$ Yoshida et al.}

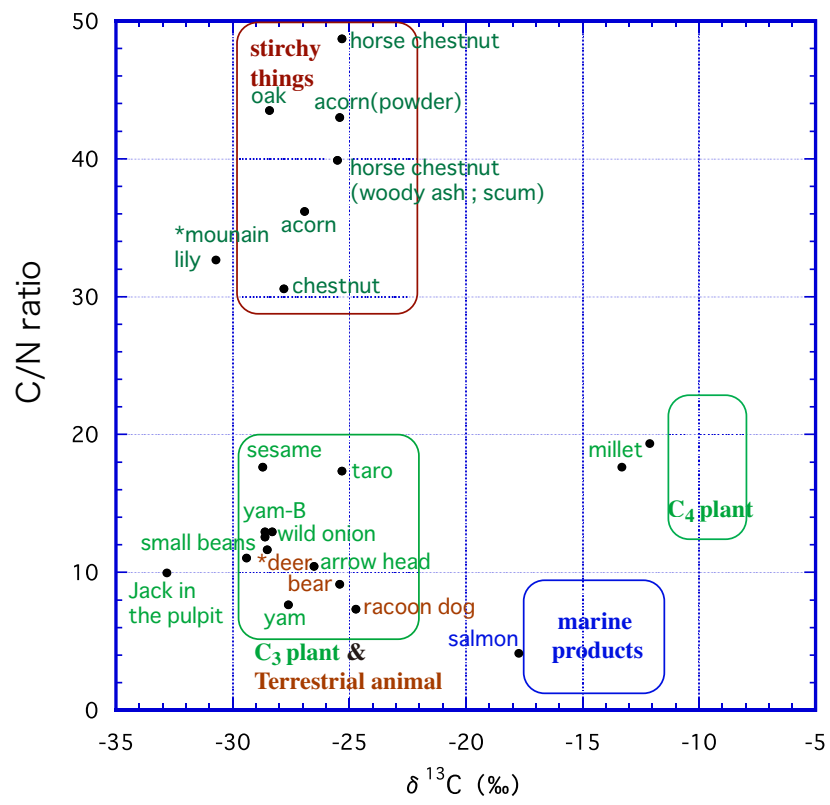

Figure $4 \mathrm{C}: \mathrm{N}$ atomic ratios of carbonized modern food components

though, the isotopic ratios did not change dramatically, confirming that carbonized residues adhered on potsherds maintain the information of cooking ingredients and are useful to estimate the origin of charred materials and to reconstruct paleodietary information.

In addition to those for single cooking ingredients, an experiment to boil multiple cooking ingredients together was conducted. Analyses are ongoing but preliminary results show that if severe diagenesis has not occurred since burial, the ingredients can probably be inferred based on the isotope composition of the charred residue left on the surface of the excavated potsherd.

\section{Estimation of Cooked Food from the Charred Residue}

Using earthenware vessels to analyze carbonized residue adhered on the potsherd constitutes a powerful tool for inference. Carbon isotope ratios and atomic ratios of carbon and nitrogen were measured for 35 samples. Nitrogen isotope ratios were analyzed for 22 samples. Samples in Table 1 were taken from the outer side of potsherd, except for the sample from Kosegasawa. In all, 45 potsherds of the Unokiminami site exist including unmeasured samples. There were 6 paired inner and outer samples. There were only inner residues for 3 samples. Some 36 samples were taken from the outside of potsherd. In the same area, there were a group of gorgeous decorated pots, called "Flame type pottery (Kaendoki)" of the Middle stage of the Jomon period, 5300-4800 cal BP. Carbonized residues adhered on the inner side or the outer of the rim (Yoshida 2012). The situation differs from that of samples from the Unokiminami site. Residues adherent on the potsherd surface might not look like soot because of their thickness. Carbon isotopic and C:N ratios were measured for 23 samples and nitrogen isotopic ratios were measured for 17 samples (Table 2).

$\mathrm{C}: \mathrm{N}$ ratios indicate that starchy things like nuts were cooked independently (Figure 5). All samples from the Kuboderaminami site, 1 sample of the Jin site, and 1 sample of the Kosegasawadoketsu site show values higher than 35 . The latter is an inner sample that unquestionably shows the results of cooking nuts alone. Based on the $\mathrm{C}: \mathrm{N}$ atomic ratios, no residue resulting from cooking nuts sepa- 
rately was found in he "flame type pottery" (Yoshida 2012). We suspect that early pottery might have been used to boil horse chestnuts and similar nuts to lessen their harsh taste.

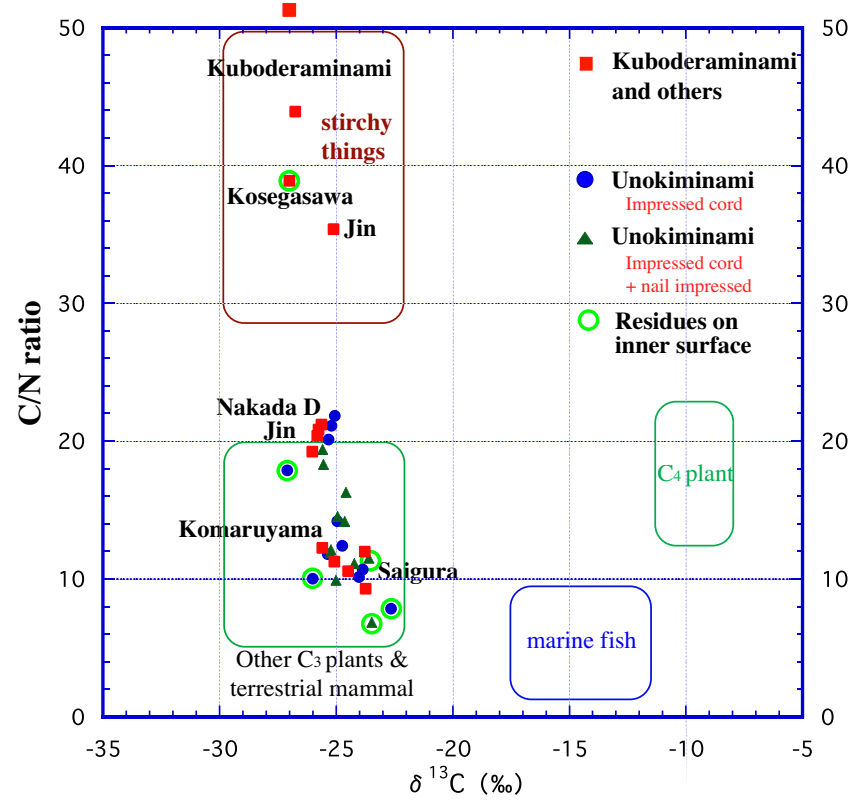

Figure $5 \mathrm{C}: \mathrm{N}$ atomic ratios of charred residues on pottery

Excluding the starchy group, no sample showed a value greater than 22 , and $\mathrm{C}: \mathrm{N}$ ratios were distributed between 9 and 22. The results suggest that 2 groups exist: one group with ratios around 20 (e.g. the Nakada D site) and another one group has ratios around 10 (Saigura and Komaruyama B sites). One $\delta^{15} \mathrm{~N}$ result was especially low, 2.1 (Figure 6).

Some 23 samples from Unokiminami site were analyzed. The C:N ratios were 6.9-11.6 for inner samples except for sample 14. $\delta^{15} \mathrm{~N}$ values higher than 7-8 suggest marine products were probably cooked in the vessels (Yoshida 2012). Many samples shown in Figure 6 have values higher than $7-$ 8. In the Tsunan-machi region of the Incipient Jomon period, marine products were cooked in Jomon pottery, which is notable since this area is $40 \mathrm{~km}$ from the sea. However, fish such as salmon and trout are present in the upper Shinano River and its tributaries. It can be presumed that these residues are products of having cooked anadromous fish such as salmon and trout. This situation is the similar to that discussed above for flame type pottery (Yoshida 2012).

Nevertheless, one important problem persists. During the Incipient Jomon period, the sea level was lower than it is now. In recent years, the situation of the Sea of Japan during the Jomon transgression from the LGM has been clarified. The Sea of Japan, with a maximum depth of $3700 \mathrm{~m}$, is connected to the open sea through 4 shallow straits: the Tsushima [Korea] Strait (130-140 m); Tsugaru Straits $(130 \mathrm{~m})$; Soya [La Pérouse] Strait $(55 \mathrm{~m})$; and Mamiya [Tatar] Strait (12 m). In the LGM, the sea level is thought to have dropped about 120-130 m, partially isolating the Sea of Japan at this time, causing an increase inflow of river water. Lee et al. (2008) pointed out that 3 straits with shallower than 130-m sills were completely closed and the Tsushima Strait (maximum sill depth of $140 \mathrm{~m}$ ) seems to have persisted as a partial connection to the East Sea. In the Incipient Jomon period, the Sea of Japan was not connected to the open sea in its northern area. It is questionable whether 


\section{$K$ Yoshida et al.}

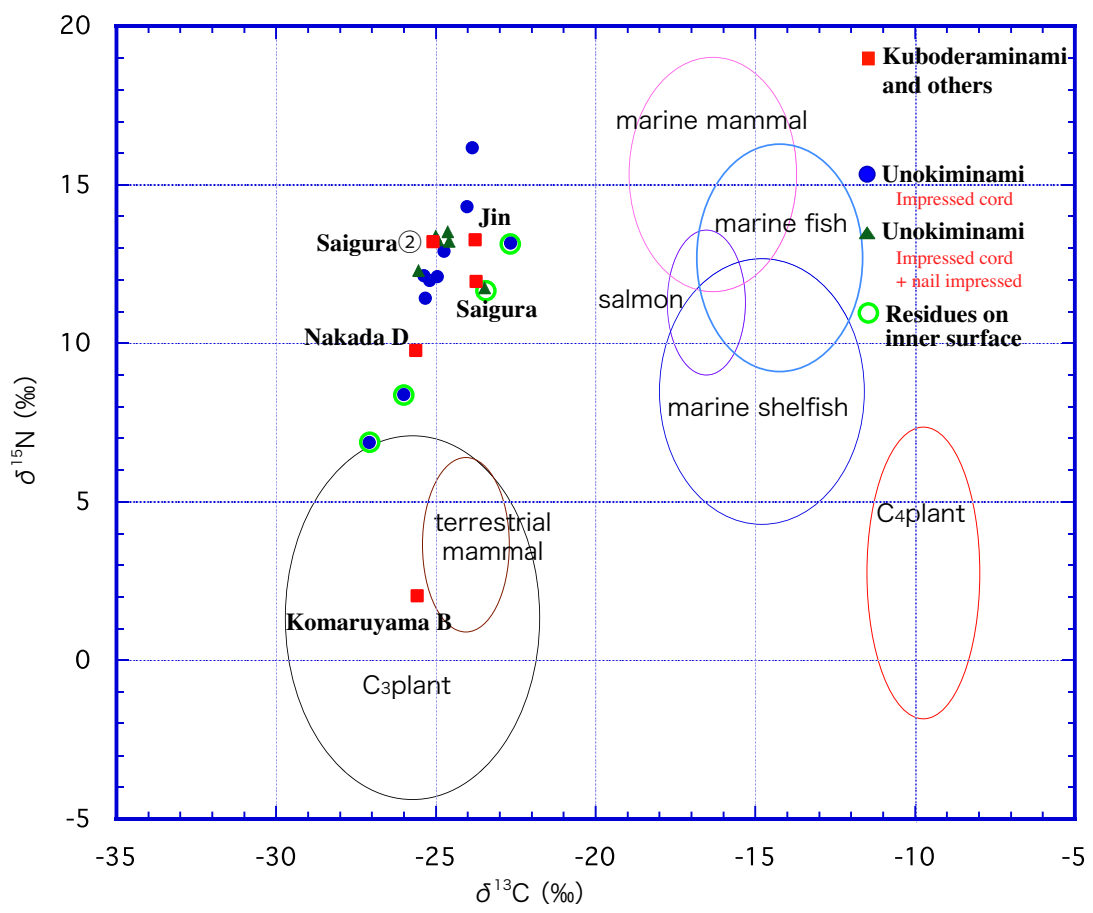

Figure 6 Carbon and nitrogen isotopic ratios of charred residues on pottery

salmon and trout were able to return to the Shinano River. The DNA analysis of population structure and stock identification of chum salmon show that the populations of Honshu and Hokkaido on the Sea of Japan coast are close genetically, although the population of the Pacific Ocean side differs (Beacham et al. 2008). Thus, it is inferred that salmon and trout were trapped in the Sea of Japan or returned through the shallow Tsugaru Strait and were thus an available food source for inhabitants at the time.

The change of in nitrogen ratios might reflect mass fractionation by carbonization. Moreover, the possibility exists of enrichment by diagenesis under the burial. It will be necessary to examine that point in the future using pyrolysis-gas chromatography/mass spectrometry, a complicated analysis that must be further developed.

\section{CONCLUSION}

The ${ }^{14} \mathrm{C}$ ages for charred residues on potteries were measured for 35 samples of the Incipient Jomon period. The calibrated ${ }^{14} \mathrm{C}$ ages for "Linear-relief type" of the Kuboderaminami site were distributed between 15,200 and 14,200 cal BP. The ages for the "pitted decoration type" of the Jin site are between 13,800 and 13,400 cal BP. The ages of "Nail-impressed type" at Saigurasite continued to $13,300 \mathrm{cal} \mathrm{BP}$, and those of the Nakada D site were between 13,400-13,100 cal BP. The calibrated ages of the Unokiminami site spanned 13,000-12,600 cal BP. Based on the C:N atomic ratios, residue resulting from cooking nuts separately is detected in early pottery. In the Tsunan region of the Incipient Jomon period, marine products were cooked in Jomon pottery. 


\section{Charred Residues on Incipient Jomon Pottery}

\section{ACKNOWLEDGMENTS}

The authors thank Mr Nobuo Miyauchi of the Tokamachi City Board of Education, and Masaichi Sato of the Tsunan Town Board of Education. This study was financially supported by Grants-inAids for Scientific Research $(11301013,14201042)$ from the Japan Society for the Promotion of Science.

\section{REFERENCES}

Beacham TD, Sato S, Urawa S, Le KD, Wetklo M. 2008. Population structure and stock identification of chum salmon Oncorhynchus keta from Japan determined by microsatellite DNA variation. Fisheries Science 74(5):983-94.

Boaretto E, Wu X, Yuan J, Bar-Yosef O, Chu V, Pan Y, Liu K, Cohen D, Jiao T, Li S, Gu H, Goldberg P, Weiner S. 2009. Radiocarbon dating of charcoal and bone collagen associated with early pottery at Yuchanyan Cave, Hunan Province, China. Proceedings of the National Academy of Sciences of the USA 106(24): 9595-600.

Boudin M, Van Strydonck M, Crombe P, De Clercq W, van Dierendonck RM, Jongepier H, Ervynck A, Lentacker A. 2010. Fish reservoir effect on charred food residue ${ }^{14} \mathrm{C}$ dates: Are stable isotope analyses the solution? Radiocarbon 52(2):697-705.

Bronk Ramsey C. 2009. Bayesian analysis of radiocarbon dates. Radiocarbon 51(1):337-60.

Bronk Ramsey C, Staff RA, Bryant CL, Brock F, Kitagawa $\mathrm{H}$, van der Plicht J, Schlolaut G, Marshall MH, Brauer A, Lamb HF, Payne RL, Tarasov PE, Haraguchi T, Gotanda K, Yonenobu H, Yokoyama Y, Tada R, Nakagawa T. 2012. A complete terrestrial radiocarbon record for 11.2 to $52.8 \mathrm{kyr}$ B.P. Science 338(6105): $370-4$.

DeNiro MJ, Hastorf CA. 1985. Alteration of ${ }^{15} \mathrm{~N} /{ }^{14} \mathrm{~N}$ and ${ }^{13} \mathrm{C} /{ }^{12} \mathrm{C}$ ratios of plant matter during the initial-stage of diagenesis: studies utilizing archaeological specimens from Peru. Geochimica et Cosmochimica Acta 49(1):97-115.

Fischer A, Heinemeier J. 2003. Freshwater reservoir effect in ${ }^{14} \mathrm{C}$ dates of food residue on pottery. Radiocarbon 45(3):449-66.

Hart JP, Lovis WA. 2007. The freshwater reservoir and radiocarbon dates on cooking residues: old apparent ages or a single outlier? Comments on Fischer and Heinemeier (2003). Radiocarbon 49(3):1403-10.

Intergovernmental Panel on Climate Change (IPCC). 2007. IPCC Fourth Assessment Report Climate Change 2007. Geneva: IPCC.

Kunikita D, Yoshida K, Miyazaki Y, Saito K, Endo A, Matsuzaki H, Ito S, Kobayashi T, Fujimoto T, Kuznetsov AM, Krupyanko AA, Tabarev AM. 2007. Analysis of radiocarbon dates of an archaeological site in the Russian Far East: the marine reservoir effect as seen on charred remains on pottery. Nuclear Instruments and Methods in Physics Research B 259(1): $467-73$.
Kuzmin YV. 2006. Chronology of the earliest pottery in East Asia: progress and pitfalls. Antiquity 80(308): 362-71.

Lee E, Kim S, Nam S. 2008. Paleo-Tsushima Water and its effect on surface water properties in the East Sea during the last glacial maximum: revisited. Quaternary International 176-177:3-12.

Lowe JJ, Rasmussen SO, Björck S, Hoek WZ, Steffensen JP, Walker MJC, Yu ZC, the INTIMATE group. 2008. Synchronisation of palaeoenvironmental events in the North Atlantic region during the Last Termination: a revised protocol recommended by the INTIMATE group. Quaternary Science Reviews 27(1-2):6-17.

Minagawa M. 2001. Dietary pattern of Prehistoric Japanese populations inferred from stable carbon and nitrogen isotopes in bone protein. Bulletin of the $\mathrm{Na}$ tional Museum of Japanese History 86:333-57. In Japanese with English summary.

Nakamura T, Taniguchi Y, Tsuji S, Oda H. 2001. Radiocarbon dating of charred residues on the earliest pottery in Japan. Radiocarbon 43(2B):1129-38.

Nishida Y. 2006. Tankabutsu no Seiseijikken [Experimental study on charred residues]. Bulletin of the Niigata Prefectural Museum of History 7:25-50. In Japanese.

Poole I, Braadbaart F, Boon JJ, van Bergen PF. 2002. Stable carbon isotope changes during artificial charring of propagules. Organic Geochemistry 33(12):167581.

Reimer PJ, Baillie MGL, Bard E, Bayliss A, Beck JW, Blackwell PG, Bronk Ramsey C, Buck CE, Burr GS, Edwards RL, Friedrich M, Grootes PM, Guilderson TP, Hajdas I, Heaton T, Hogg AG, Hughen KA, Kaiser KF, Kromer B, McCormac FG, Manning SW, Reimer RW, Richards DA, Southon JR, Talamo S, Turney CSM, van der Plicht J, Weyhenmeyer CE. 2009. IntCa109 and Marine09 radiocarbon age calibration curves, 0-50,000 years cal BP. Radiocarbon 51(4): 1111-50.

Shimojo H. 1988. Basic study for reconstruction of human diet in the Okadaira shell midden by carbon and nitrogen isotope analysis [Master's thesis]. The University of Tokyo. In Japanese.

Taniguchi Y. 2011. Jomonbunkakigenron no Saikouchiku [Reconstruction of theory for origin of Jomon culture]. Tokyo: Doseisha. In Japanese.

Tsuji S. 2001. Kuboderaminamiisekishutsudo no Doki ni Fuchakushita Tankabutsu no Hoshaseitansonendai [Radiocarbon age of charred residues adhered on pot- 


\section{K Yoshida et al.}

tery excavated from the Kuboderaminami site]. Kuboderaminamiiseki: Nakazato-mura Board of Education. p 243-5. In Japanese.

Walker PL, DeNiro MJ. 1986. Stable nitrogen and carbon isotope ratios in bone collagen as indices of prehistoric dietary dependence on marine and terrestrial resources in Southern California. American Journal of Physical Anthropology 71(1):51-61.

Wu X, Zhang C, Goldberg P, Cohen D, Pan Y, Arpin T, Bar-Yosef O. 2012. Early pottery at 20,000 years ago in Xianrendong Cave, China. Science 336(6089): 1696-700.

Yoneda M, Shibata Y, Morita M, Hirota M, Suzuki R, Uzawa K, Ohshima N, Dodo Y. 2004a. Interspecies comparison of marine reservoir ages at the Kitakogane shell midden, Hokkaido, Japan. Nuclear Instruments and Methods in Physics Research B 223-224:376-81.

Yoneda M, Suzuki R, Shibata Y, Morita M, Sukegawa T, Shigehara N, Akazawa T. 2004b. Isotopic evidence of inland-water fishing by a Jomon population excavated from the Boji site, Nagano, Japan. Journal of Archaeological Science 31(1):97-107.
Yoshida K. 2006. Nitakishite dekita Tankabutsu no Doitaibunseki [Isotope analysis of charred residues]. Bulletin of the Niigata Prefectural Museum of History 51:51-8. In Japanese.

Yoshida K. 2012. Koshokuseibunseki (Jomonjin no Shokutaku) [Dietary reconstruction based on stable isotopes in the Japanese Archipelago]. In: Yoshida K, editor. Arukeometoria - Kokoibutsu to Bijutsukogeihin wo Kagaku no Me de Sukashimiru [Archaeometria - Scientific Research for Artifact]. Tokyo: University Museum, University of Tokyo. p 43-55.

Yoshida K, Miyazaki Y. 2001. Methods of radiocarbon dating at Tell Kosak Shamali. In: Nishiaki Y, editor. Tell Kosak Shamali. UMUT Monograph 1. Tokyo: University Museum, University of Tokyo. p 158-63. In Japanese with English summary.

Yoshida K, Ohmichi J, Kinose M, Iijima H, Oono A, Abe N, Miyazaki Y, Matsuzaki H. 2004. The application of ${ }^{14} \mathrm{C}$ dating to potsherds of the Jomon period. Nuclear Instruments and Methods in Physics Research B 223224:716-22. 